\title{
Dedication: Michael J. Taylor
}

John R. Bryson

\section{Pioneer in the study of industrial geography, business processes, local economic development, and the theory of the firm}

This edited collection is dedicated to Michael (Mike) J. Taylor in recognition of his academic leadership in the field of economic geography. Mike was one of the world's foremost economic geographers and is best known for his important contributions to the study of business enterprise and local development in the context of understanding the constraints on local growth imposed by processes of global change. He retired from the Chair of Human Geography at the School of Geography, Earth and Environmental Sciences, University of Birmingham, UK, in September 2011 and died at Bunbury, Western Australia on 22 May 2021, leaving a highly influential legacy of research and publications.

Following his undergraduate studies in geography and a $\mathrm{PhD}$ that explored spatial linkage and the West Midlands iron foundry industry at University College London (UCL), Mike developed an academic career that included posts at Auckland, Australian National University (ANU), UWA, Portsmouth and Birmingham (UK). He also held adjunct positions at the University of Western Australia (UWA) and the University of the Sunshine Coast (USC), Australia. His early publications focused on industrial geography with a focus on behavioural dimensions of economic activities. This includes his 1982 book co-authored with Philip McDermot on Industrial Organisation and Location. This book was an important contribution, as it set out to establish a geography of organizations, to develop an adequate conceptualization of the organization in industrial geography and to make a major contribution to micro-scale studies. Mike was one of the first geographers to recognize the growing importance of exploring micro-scale processes and developing a geography of firms and of firm behaviour. He pioneered research on business organization, segmentation and location by developing a process-oriented account (Taylor 
and Thrift, 1982a, 1982b, 1983) and published one of the first edited collections on the geography of multinationals (Taylor and Thrift, 1982c). He published over 150 papers and book chapters, and 15 books. Without question, Mike's work helped shape the study of manufacturing industries, local economic development, and geographical approaches to theorizing firms in place and across space.

Many of the world's most prominent economic geographers worked with Mike during his research career. His research both shaped academic debates, but informed policy development in the United Kingdom, New Zealand and Australia (Taylor, 2000). One of his cross-cutting research interests revolved around the theory of the firm and the concept of the firm in economic geography (Taylor and Asheim, 2001; Taylor and Oinas, 2006). This included research on temporary coalitions (Taylor, 1999), clusters (Taylor, 2010), and corporate location and performance (Tonts and Taylor, 2010). Much of his research included an Australian or West Midlands (UK) focus. The West Midlands work produced a set of papers on manufacturing that commenced with his early work on local linkage and iron foundries (Taylor, 1973, 1978), and concluded with papers on the manufacture of locks (Bryson et al., 2008) and group contracting and the organization of production in Birmingham in the nineteenth century (Bryson and Taylor, 2010). Throughout his publications there is a very clear emphasis placed on theory development and testing. This includes contributions to the theory of the firm (McDermot and Taylor, 1982; Taylor and Asheim, 2001; Taylor and Oinas, 2006), theories of local economic growth (Plummer and Taylor, 2001a, 2001b, 2003) and enterprise power (Taylor, 1996).

Mike had many talents. Despite undertaking a formidable amount of cutting-edge research, Mike was also an excellent $\mathrm{PhD}$ supervisor and teacher. He was always making something, and engaged in building and construction activities on his home. Making also included making stained glass windows, decorating cakes, and he was also a remarkably accomplished seamster. The latter talent included making ball gowns, bridesmaids' dresses and even wedding dresses.

It is appropriate that this book should be dedicated to Mike, given the contributions he made to unravelling the changing geography of manufacturing organizations and in understanding the spatial and organizational dimensions of firms. Mike liked to question existing approaches to understanding firms in place and space, and to identify new research agendas. 


\section{References}

Bryson, J.R. and Taylor, M. (2010), 'Mutual dependency, diversity and alterity in production: cooperatives, group contracting and factories', in Fuller, D., Jonas, A.E.G. and Lee, R. (eds), Interrogating Alterity, Farnham: Ashgate, 75-94.

Bryson, J.R., Taylor, M. and Cooper, R. (2008), 'Competing by design, specialization and customization: manufacturing locks in the West Midlands (UK)', Geografiska Annaler: Series B, Human Geography, 90 (2), 173-186.

McDermot, P. and Taylor, M. (1982), Industrial Organisation and Location, Cambridge: Cambridge University Press.

Plummer P. and Taylor M. (2001a), 'Theories of local economic growth (part 1): concepts, models, and measurement', Environment and Planning A: Economy and Space, 33 (2), 219-236.

Plummer P. and Taylor M. (2001b), 'Theories of local economic growth (part 2): model specification and empirical validation', Environment and Planning A: Economy and Space, 33 (3), 385-398.

Plummer P. and Taylor, M. (2003), 'Theory and praxis in economic geography: “enterprising" and local growth in a global economy', Environment and Planning C: Politics and Space, 21 (5), 633-649.

Taylor, M.J. (1973), 'Local linkage, external economies and the iron foundry industry of the West Midlands and East Lancashire conurbations', Regional Studies, 7, 387-400.

Taylor, M.J. (1978), 'Linkage change and organisational growth: the case of the West Midlands iron foundry industry', Economic Geography, 54, 314-336.

Taylor, M.J. (1996), 'Industrialisation, enterprise power, and environmental change: an exploration of concepts', Environment and Planning A, 28, 1035-1051.

Taylor M.J. (1999), 'The small firm as a temporary coalition', Entrepreneurship and Regional Development, 11 (1), 1-19.

Taylor, M. (2000), 'The dynamics of Australian regional policy: lessons for Europe?', Regional and Federal Studies, 10 (2), 107-125.

Taylor, M. (2010), 'Clusters: a mesmerising mantra', Tijdschrift voor economische en sociale geografie, 101, 276-286.

Taylor, M. and Asheim, B. (2001), 'The concept of the firm in economic geography', Economic Geography, 77, 315-328.

Taylor, M. and Oinas, P. (2006), Understanding the Firm: Spatial and Organizational Dimensions, Oxford: Oxford University Press.

Taylor, M.J. and Thrift, N.J. (1982a), 'Industrial linkage and the segmented economy: 1. Some theoretical proposals', Environment and Planning A, 14, 1601-1613.

Taylor, M.J. and Thrift, N.J. (1982b), 'Industrial linkage and the segmented economy: 2. An empirical reinterpretation', Environment and. Planning A, 14, 1615-1632.

Taylor, M.J. and Thrift, N.J. (eds) (1982c), The Geography of Multinationals, London: Croom Helm.

Taylor, M. and Thrift, N. (1983), 'Business organization, segmentation and location', Regional Studies, 17 (6), 445-465.

Tonts, M. and Taylor, M. (2010), 'Corporate location, concentration and performance: large company headquarters in the Australian urban system', Urban Studies, 47 (12), 2641-2664. 
John R. Bryson - 9781789908510 Downloaded from PubFactory at 04/26/2023 01:10:12PM via free access 